\title{
THE ROLE OF JOB CRAFTING IN THE RELATIONSHIP BETWEEN EMPOWERING LEADERSHIP AND HAPPINESS AT WORK: AN EMPIRICAL ANALYSIS
}

\author{
Mohammed Yasin GHADI ${ }^{1^{*}}$, Khaled Salameh ALMANAGA'H ${ }^{2}$ \\ ${ }^{1}$ Hamdan Bin Mohammed Smart University, Dubai, United Arab Emirates \\ ${ }^{2}$ Univeristi Malaysia Terengganu, AlKarak, Malaysia
}

Received 26 August 2019; accepted 6 December 2019

\begin{abstract}
The purpose of this study is to examine a hypothesized model investigating the impact of empowering leadership on happiness at work through the mediating role of job crafting. A translated pre-determined survey on a sample of Jordanian academics was used. A total of 325 usable returns were collected for the analysis (i.e. a response rate of 84.6 percent). Structural equation model (SEM) using AMOS was implemented to obtain the best-fit model and to determine the role of job crafting as a potential mediator between empowering leadership and happiness at work. The results indicated no direct statistical effect for empowering leadership on happiness at work with an estimated value of 0.17 and a standard error of 0.073. The results also show that there was a significant statistical effect for empowering leadership on crafting and this effect was high with a value of 0.479 and a standard error of 0.040 . Finally, the results revealed a direct effect for empowering leadership on happiness at work through the mediating role of job crafting. The study recommended that it is necessary for universities to offer new programs and workshops that improve the behaviors of empowering leadership in light of work conditions at various levels and to motivate job crafting to increase levels of happiness at work.
\end{abstract}

Keywords: empowering leadership, job crafting, task crafting, relationship crafting, happiness at work.

JEL Classification: M12, M14.

\section{Introduction and literature review}

This era is characterized by fast developments and changes. This influences the business environment at all levels and aspects as these developments and changes are related to the external environment such economic, social, political and technological conditions or the internal environmentrelated changes such as organizational culture, leadership, and human resources practices.

In light of such changes, business organizations need to select the best leadership style and to apply all possible methods and tools that reinforce organizations' abilities and investing their financial and human resources to achieve the organization's various goals. Among these methods and tools is a clear strategy-based leadership that is an integral part of the organization, which cannot be dispensed, and all organizations work on developing it and are interested with it (Esteves \& Lopes, 2016; Golparvar \& Rezaie, 2014).

There have been many leadership methods that could be used for business within organizations and to regulate their tasks to achieve the desired achievement efficiently. Among these methods, is empowering leadership, which aims to engage employees within the organization in decision, making processes and resolving problems in addition to delegating them authority and offering appropriate work environment to achieve the organization's goals and to increase performance level (Pearce \& Sims, 2002). Empowering leadership also reinforces the self-development and self-leadership of employees; hence, higher levels of commitment among them are achieved (Esteves \& Lopes, 2016).

It has been argued that empowering leadership is a basic process for stimulating individuals and increasing their morals, which in turn is reflected on their performance and levels of job satisfaction, which in turn affects achieving organizational goals efficiently for the organization (Ayasrah, 2008). Furthermore, empowering leadership is one of leadership styles within which the leader works on enrolling employees in the leadership process and makes them hold liabilities as such a leader plays an integral role in motivating individuals' behavior toward excellence in

${ }^{*}$ Corresponding author. E-mail: mghadi@hbmsu.ac.ae 
job behavior which in turn is positively reflected a higher level of organizational loyalty (Altamimi, 2004). Empowering leadership can be defined as providing employees with an opportunity to hold responsibility for what they do of work and tasks related to the services or production and delegating them to make decisions and conducting procedures related to their responsibilities and tasks at the organization level (Jallab \& Alhusaini, 2013).

It is necessary to know that leadership empowerment is based on a group of basic dimensions to achieve its goals and purposes. For example, Ayasrah (2008) indicated these dimensions are: first, the sequence in employees' empowerment begins with determining their tasks and responsibilities within limits and giving them the opportunity to select their roles reaching to fully empowering them and relying on them in decision-making. Second, directing employees, supervising them and providing them with what they need of information for decision making or continuously achieving their tasks. Third, reinforcing individual and group work values among employees to be able to cooperate and work with one team spirit to reach the level where the team manage itself without needing control or instruction.

On the other hand, the concept of happiness at work is one of the recent concepts in business, which was the focus of the studies of Dolan (2008) and Lyubomirsky (2005). The concept of happiness at work indicates the extent to which the organization and the management provide an appropriate work environment for employees that makes them loyal and to the organization. This in turn makes it a pioneer in its field as providing with luxury, as a general level within the institution is one of the important factors that distinguish the organization through the administrative and the various leadership styles such as applying empowering leadership.

In other words, happiness at work environment and achieving it for employees positively and efficiently works when it is transformed into a daily routine within the work place and makes positive feelings the controller against negative ones resulted from exhaustion or any other stresses (Olsson, 2013).

Job development theories have early emerged but researchers started testing the efficiency of job development before only four decades (Richard, 2005), and it is not surprising to find many efforts today focused on studying professional development and institutions' adherence to it as indicated by Cohen (2007). In this regard, Okurame (2014) indicates that modern institutions' employees need to adopt stable changes and there should be continuous training on job development. Çiğdem Kaya and Belgin (2014) indicate that when the organization has an efficient job development, programs in line with employee's expectations, the employee's loyalty will be for this organization and will be reflected on his/her performance with time. In particular, when managers realize that there will not be a performance at the desired level among employees with the absence of professional managerial practices and job development.
According to (Berg, 2013), the concept of job crafting is one of the new managerial concepts that mainly indicates the changes occur on tasks whether on the tasks performed by individuals or the relationships among them and based on this concept employees can better implement work and arrange priorities to facilitate their abilities and preferences in work achievement. He indicated that job crafting is divided into three main types: task crafting, relationship, and knowledge crafting. The first type indicates that the process of changing the task limits by adding more beneficial tasks or excluding the undesired ones, changing the time specified for achieving tasks and implementation priorities in addition to modifying implementation methods to be easier. The second type (i.e., relationship crafting) indicates the process of changing social relationships among employees and their positions, this includes modifying the why and when process, and with whom an employee interacts when performing job tasks to be more beneficial. The third type (i.e., knowledge crafting), indicates the process of changing the methods and ways by which they view or think about their job tasks by changing employees' perspectives toward their tasks (Grant \& Parker, 2009).

Based on the above mentioned, this study attempts to examine the mediating role of job crafting on the relationship between empowering leadership and happiness at work.

\section{Statement of the problem}

The problem of the study lies in that the work environment of faculty members in the south of Jordan is considered an expelling environment, where the universityworking environment is not attractive anymore. This, in turn, leads faculty members to leave their work and move to work elsewhere. In addition, there is alarming evidence about Jordanian academics as there are about $3000 \mathrm{mem}$ bers have left their work during the last 25 years, and during the last eight years, there were $20 \%$ of Jordanian academics planning to seek opportunities in other fields and this percentage is expected to reach $60 \%$ by the year 2020 (Ghadi, 2017).

Based on the above mentioned, the problem of the study is represented by answering the following two research main questions:

- Q1: Is there an effect for empowering leadership on achieving happiness at work among faculty members within university work environment?

- Q2: Is there a direct effect for job crafting on achieving happiness at work among faculty members within university work environment? How?

\section{Hypotheses}

Hypothesis 1: There is no statistical significant effect for using leadership empowerment on achieving happiness at work among faculty members in south Jordan universities. 
Hypothesis 2: There is no statistical significant effect for job crafting as an intermediate variable on the relationship between leadership empowerment and happiness at work among faculty members in south Jordan universities.

\section{Procedural definitions of the terms}

Empowering Leadership: a group of behaviors practiced by manager at work with employees and these behaviors includes mandating tasks and responsibilities to employees in addition to reinforcing subordinates' self-leadership and enabling them to make decisions alone (Ahrarn et al., 2005).

Job crafting: a group of modifications conducted by individuals at the level of job content and tasks in a manner appropriate for their skills and abilities, and this is defined as redesigning and this is an initiation from the employee and not required by higher management (Wrzesniewski \& Dutton, 2001). Tasks crafting: modifying job responsibilities included within job descriptions and positions through adding or removing a group of tasks or modifying their nature and the necessary time for a task achievement based on employees' abilities and skills. Relationships crafting: Giving the employee an opportunity to construct job relationships within work based on what he/she sees as appropriate and selecting with whom he/ she interacts during work implementation (Berg, 2013).

Happiness at Work: a group of programs and initiations and services that aim to reinforce employees' psychological, mental and physical health for their importance in developing their behavior and job performance and their productivity as well as facilitating their motivation for work which positively reflected on their happiness and loyalty and organizational belonging (Dutton, \& Edmunds, 2007).

\section{Previous studies}

Kim and Beehr (2018) investigated the effect of leadership empowerment on employees' luxury through their job crafting behavior. The study followed the analytical descriptive approach to achieve its goals. Results indicated a positive relationship between leadership empowerment and job crafting and indicated that job crafting reinforces job satisfaction and employees' commitment at work and that leadership empowerment has a role in encouraging and facilitating job crafting.

The study of Bell and Njoli (2010) aimed to identify the most five characteristics exhibited by employees and affect managers' attitudes toward supporting job crafting in institutions. The researchers used the analytical descriptive approach to achieve the goal of the study. The sample included 246 managers in Alice city in North Africa. Results indicated the most characteristics exhibited by employees and affect managers' attitudes toward supporting job crafting in institutions. First, diligence, that is, the employee's tendency to exhibit self-discipline and efficiency. Second, happiness, that is, employee's tendency to stimulation and enjoyment with others within work environment. Third, acceptance, that is, employee's cooperation with colleagues at work and 4-openness to other experiences.

Esteves and Lopes' study (2016) investigated the relationship between leadership and job crafting and relations' crafting. The sample included 325 nurses and the study followed the analytical descriptive approach. It was revealed that leadership style had a strong relationship with increasing changes within work environment.

A'ffanah (2013) investigated the relationship between managerial empowerment and work teams' efficiency and the level of applying each of them in international NGOs operating in Gaza strip. The analytical descriptive approach was utilized in the study and the population was all employees in the 65 international NGOs in Gaza strip from which 7 institutions were selected based on employees' number and the sample was consisted of 300 employees. Results indicated a high level of managerial empowerment in the international NGOs in Gaza strip, and also indicated statistical significant differences among respondents' responses about the relationship between managerial empowerment with the efficiency of team work and these differences are attributed to the age variable, and when this relation was assessed, a strong relationship was indicated.

\section{Methodology}

The study followed the analytical descriptive approach that includes a survey to construct the theoretical framework and field investigation.

\subsection{Population and sample}

The population of the study included all faculty members (Professors, Associate Professors, Assistant Professors and Lecturers) in public universities in southern governorates (Mu'tah University in Karak, Alhusien Bin Talal University in Maan, and the Technical University in Tafila and the University of Jordan in Aqaba). The total number of faculty members in these universities was 1295 academics according to the data from employees' affairs departments in these universities. From this population a sample of 325 faculty members with various academic positions whom were selected using the stratified method and were distributed as shown in Table 1.

Table 1. Distribution of the study sample according to the population and university

\begin{tabular}{|c|l|c|c|c|}
\hline & \multicolumn{1}{|c|}{ University } & Population & Sample & $\begin{array}{c}\text { Represen- } \\
\text { tation }\end{array}$ \\
\hline 1 & Mu'tah University & 615 & 155 & $25 \%$ \\
\hline 2 & $\begin{array}{l}\text { Alhusien bin Talal } \\
\text { University }\end{array}$ & 340 & 85 & $25 \%$ \\
\hline 3 & $\begin{array}{l}\text { Tafila Technical } \\
\text { University }\end{array}$ & 240 & 60 & $25 \%$ \\
\hline 4 & $\begin{array}{l}\text { The University of } \\
\text { Jordan in Aqaba }\end{array}$ & 100 & 25 & $25 \%$ \\
\hline & Total & 1295 & 325 & $100 \%$ \\
\hline
\end{tabular}




\subsection{Tool of the study}

A number of studies were used to develop the questionnaire of the study (Loqasi, \& Loqasi, 2015; A'ffanah, 2013). The questionnaire in its initial form consisted of 30 items and was subscribed to five specialists in business administration at Mu'tah University to check the face validity of the questionnaire and to take their opinions and conduct the necessary modifications.

\subsection{Validity}

Validity of the study tool was determined as follows. First, content Validity. Based on the opinion of the specialists, some items was not changed or modified and others were reformulated and modified accordingly. Second, construct Validity. After modifying the questionnaire as suggested by the specialists, the questionnaire was distributed on a pilot sample of 30 participants from the population of the study. After this pilot testing, a correlation test was conducted for the questionnaire items and the dimensions. Namely, Pearson correlations were calculated among the tool's dimensions and the total score as indicated in Table 2 .

Table 2. Tool's correlations with its dimensions and the total score and Pearson correlations among the dimensions' total score

\begin{tabular}{|c|l|c|}
\hline No & \multicolumn{1}{|c|}{ Dimension } & $\begin{array}{c}\text { Dimension correlation } \\
\text { with the total score }\end{array}$ \\
\hline 1 & Empowering leadership & 0.77 \\
\hline 2 & Happiness at work & 0.84 \\
\hline 3 & Tasks crafting & 0.77 \\
\hline 4 & Relationships crafting & 0.75 \\
\hline
\end{tabular}

Table 2 indicates that the general dimensions of study with correlation of dimensions with total score ranged between 0.71 and 0.84 , The values of correlations are acceptable for the purposes of this study.

\subsection{Reliability}

Reliability was checked through the following tests:

- Split-Half Reliability: the scale (questionnaire) was applied on a pilot sample of 30 participants from the

Table 3. Split-Half reliability correlations and Cronbach Alpha for internal consistency for the tool dimensions and the total score

\begin{tabular}{|c|l|c|c|}
\hline No & \multicolumn{1}{|c|}{ Dimension } & Split-Half & $\begin{array}{c}\text { Cronbach } \\
\text { Alpha }\end{array}$ \\
\hline 1 & $\begin{array}{l}\text { Leadership } \\
\text { Empowerment }\end{array}$ & 0.81 & 0.82 \\
\hline 2 & Happiness at Work & 0.72 & 0.69 \\
\hline 3 & Tasks' Crafting & 0.67 & 0.60 \\
\hline 4 & $\begin{array}{l}\text { Relationships } \\
\text { Crafting }\end{array}$ & 0.83 & 0.88 \\
\hline 5 & Total Score & 0.92 & 0.90 \\
\hline
\end{tabular}

study population but other than its sample and then Gilt Man Split-Half correlations were calculated as shown in Table 3.

- Reliability correlations were calculated using Cronbach alpha as shown in Table 3.

Table 3 indicates that the split-half correlations of the questionnaire's dimensions ranged between 0.67 and 0.83 and reached 0.92 for the total score, in addition, Cronbach alpha values ranged from 0.60 to 0.88 for the dimensions with a total score of 0.90 . These values are acceptable for the purposes of this study.

\subsection{Questionnaire in its final form}

In its final form, the questionnaire was consisted of 29 items that were distributed on four main dimensions. Table 4 shows the distribution of the tool items on their dimensions as well as their lower and higher scores in addition to items indicating each dimension.

Table 4. Questionnaire dimensions and items

\begin{tabular}{|c|l|c|c|c|c|}
\hline No & Dimensions & $\begin{array}{c}\text { Items' } \\
\text { No }\end{array}$ & $\begin{array}{c}\text { Lower } \\
\text { Scores }\end{array}$ & $\begin{array}{c}\text { Higher } \\
\text { Scores }\end{array}$ & $\begin{array}{c}\text { Items } \\
\text { Repre- } \\
\text { senting } \\
\text { Dimensions }\end{array}$ \\
\hline 1 & $\begin{array}{l}\text { Leadership } \\
\text { Empowerment }\end{array}$ & 8 & 8 & 40 & $1-8$ \\
\hline 2 & $\begin{array}{l}\text { Happiness at } \\
\text { Work }\end{array}$ & 8 & 8 & 40 & $9-16$ \\
\hline 3 & Tasks' crafting & 8 & 8 & 40 & $17-24$ \\
\hline 4 & $\begin{array}{l}\text { Relationships } \\
\text { crafting }\end{array}$ & 5 & 5 & 25 & $25-29$ \\
\hline 5 & Total Score & 29 & 29 & 145 & $1-29$ \\
\hline
\end{tabular}

\subsection{Statistical treatment}

Pearson, Gilt Man, Spearman correlations and Cronbach alpha were used to in the statistical treatment. To test the first and second hypotheses the SEM and the EFA tests were used.

\section{Results}

\subsection{Testing the study first hypothesis}

To test this hypothesis, which is expressed by Table 5 below, standard regression was calculated for variables as shown in Table 5.

Table 5. Standard values of $\mathrm{H} 1$ variables

\begin{tabular}{|c|c|c|c|c|}
\hline \multirow{2}{*}{ Path } & \multicolumn{3}{|c|}{ Regression standard values } \\
\cline { 2 - 5 } & Estimate & $\begin{array}{c}\text { Standard } \\
\text { Error }\end{array}$ & $\begin{array}{c}\text { Regres- } \\
\text { sion } \\
\text { critical } \\
\text { value }\end{array}$ & Sig \\
\hline $\begin{array}{l}\text { Empowering } \\
\text { leadership } \rightarrow \\
\text { Happiness at work }\end{array}$ & 0.17 & 0.073 & 2.301 & 0.02 \\
\hline
\end{tabular}


Table 5 indicates that there is no statistical significant effect of leadership empowerment on happiness at work as it is indicated that the effect is low with estimated value of (0.17) with a high standard error of (0.073) and the critical value is (2.301) which is a low one and statistically insignificant as shown in the statistical significance of (0.02).

\subsection{Testing the second hypotheses}

To test this hypothesis, regression standard values were calculated as shown in Table 6.

Table 6. Regression standard values for the second hypothesis

\begin{tabular}{|l|c|c|c|c|}
\hline \multirow{2}{*}{ Path } & \multicolumn{4}{|c|}{ Regression standard values } \\
\cline { 2 - 5 } & Estimated & $\begin{array}{c}\text { Standard } \\
\text { error }\end{array}$ & $\begin{array}{c}\text { Regression } \\
\text { critical } \\
\text { value }\end{array}$ & Sig \\
\hline $\begin{array}{l}\text { Empowering } \\
\text { leadership } \rightarrow \\
\text { Tasks crafting }\end{array}$ & .273 & .039 & 6.981 & $* * *$ \\
\hline $\begin{array}{l}\text { Empowering } \\
\text { leadership } \rightarrow \\
\text { Relationships } \\
\text { crafting }\end{array}$ & .479 & .040 & 12.039 & $* * *$ \\
\hline $\begin{array}{l}\text { Relationship } \\
\text { crafting } \rightarrow \\
\begin{array}{l}\text { Happiness at } \\
\text { work }\end{array}\end{array}$ & .320 & .081 & 3.978 & $* * *$ \\
\hline $\begin{array}{l}\text { Task crafting } \\
\rightarrow \text { Happiness } \\
\text { at work }\end{array}$ & .108 & .082 & 1.320 & .187 \\
\hline
\end{tabular}

Table 6 indicates a statistical significant effect for leadership empowerment on tasks' crafting as the effect value is shown to be high and estimated with (0.273) with a standard error of (0.039) and a regression critical value of $6.981)$ and this is a significant value is indicated by (0.000).

In addition, results indicated a statistical significant effect for leadership empowerment on relationships' crafting with estimated value of (0.479) and a standard error of (0.040) where the critical value of regression is (12.039) and this is a significant one as indicated by the value of $(0.000)$. It is also indicated that there is a statistical significant effect for relationships' crafting on happiness at work with a high estimated effect of (0.320) with a standard error of (0.081) and a regression critical value of (3.987) and this is a significant value as indicated by the significance value of (0.000). Finally, results indicated no statistical significant effect for tasks' crafting on happiness at work as the effect estimated value is low and reached (0.108) with a high standard error of (0.082) and a regression critical value of (1.320) and this value is low as indicated by the significance value of (0.187).

\subsection{Model modification indices}

Results in general indicated that the data wasn't identical to the default model in this study, and also indicated the weakness of coefficients in the interpretation of the dependent variable through the casual paths existed within the default model, therefore, model modification indices were calculated as shown in Table 7.

Table 7. Default model modification indices

\begin{tabular}{|c|c|l|}
\hline Parameter Change & $\begin{array}{c}\text { Modification } \\
\text { indices }\end{array}$ & \multicolumn{1}{|c|}{$\begin{array}{c}\text { Proposed } \\
\text { Modification }\end{array}$} \\
\hline .109 & 48.616 & e2 <--> e3 \\
\hline .073 & .168 & $\begin{array}{l}\text { Leadership empo- } \\
\text { werment } \rightarrow \text { happi- } \\
\text { ness at work }\end{array}$ \\
\hline .082 & .108 & $\begin{array}{l}\text { Tasks' crafting } \rightarrow \\
\text { happiness at work }\end{array}$ \\
\hline
\end{tabular}

Table 7 indicates two kinds of proposed modification based on the model modification indices, the first is regarding the estimation errors are correlated and this proposal doesn't add too much from theoretical perspective although it modifies the statistical values for model conformity. The second is related to excluding the paths of leadership empowerment and tasks' crafting effect on happiness at work and adding the path of relationships' crafting on tasks' crafting therefore the second one is taken into account.

\subsection{The proposed model}

This model was developed according to excluding the paths of leadership empowerment and tasks' crafting effects on happiness at work and adding the paths of relationships' crafting on tasks' crafting.

Table 8 indicates the proposed indices of the absolute conformity and it is shown that the number of parameters within the default model are 14 ones which indicate the number of variables and paths between these variables compared the less determined model (saturated model) which reached 25 and that more determined model which reached 9 ones. Table 8 also indicates that the proposed model confirms the study data where Chi2 reached (1.478) with a freedom degree of (1) and a statistical significance of (0.224).

Table 8. Chi2 results for conformity

\begin{tabular}{|l|c|c|c|c|c|}
\hline \multicolumn{1}{|c|}{ Model } & NPAR & CMIN & $\begin{array}{c}\text { Degree } \\
\text { freedom }\end{array}$ & Sig & $\begin{array}{c}\text { CMIN/ } \\
\text { DF }\end{array}$ \\
\hline $\begin{array}{l}\text { Default } \\
\text { Model }\end{array}$ & 13 & 1.478 & 1 & .224 & 1.478 \\
\hline $\begin{array}{l}\text { Saturated } \\
\text { Model }\end{array}$ & 14 & .000 & 0 & - & - \\
\hline $\begin{array}{l}\text { Indepen- } \\
\text { dence } \\
\text { Model }\end{array}$ & 8 & 271.743 & 6 & .000 & 45.291 \\
\hline
\end{tabular}

Then, the other conformity indices related to the proposed model were tested according to the absolute conformity indices and comparative conformity as well as simplicity conformity as shown in Table 9. 
Table 9. Absolute conformity values

\begin{tabular}{|l|c|c|c|}
\hline Indices & $\begin{array}{c}\text { Default } \\
\text { Model }\end{array}$ & $\begin{array}{c}\text { Saturated } \\
\text { Model }\end{array}$ & $\begin{array}{c}\text { Independence } \\
\text { Model }\end{array}$ \\
\hline NFI & 0.995 & 1 & 0 \\
\hline RFI & 0.967 & - & 0 \\
\hline IFI & 0.998 & 1 & 0 \\
\hline TLI & 0.989 & - & 0 \\
\hline CFI & 0.998 & 1 & 0 \\
\hline RMSEA & .038 & - & .370 \\
\hline LO 90 & .000 & - & .333 \\
\hline
\end{tabular}

Table 9 indicates that the proposed model achieves all conformity indices whether those related to the absolute conformity or those related to comparative conformity or conformity via model simplicity.

\subsection{Regression standard values related to the proposed model}

Table 10 indicates the regression standard values for variables as determined in the proposed model.

Table 10. Regression standard values for variables as determined in the proposed model

\begin{tabular}{|l|c|c|c|c|}
\hline \multirow{2}{*}{ Path } & \multicolumn{3}{|c|}{ Regression standard values } \\
\cline { 2 - 5 } & $\begin{array}{c}\text { Esti- } \\
\text { mated }\end{array}$ & $\begin{array}{c}\text { Standard } \\
\text { error }\end{array}$ & $\begin{array}{c}\text { Regression } \\
\text { critical } \\
\text { value }\end{array}$ & Sig \\
\hline $\begin{array}{l}\text { Leadership empo- } \\
\text { werment } \rightarrow \\
\text { Relationships } \\
\text { crafting }\end{array}$ & .479 & .040 & 12.039 & $* * *$ \\
\hline $\begin{array}{l}\text { Leadership empo- } \\
\text { werment } \rightarrow \text { Tasks' } \\
\text { crafting }\end{array}$ & .091 & .043 & 2.089 & .037 \\
\hline $\begin{array}{l}\text { Relationships' } \\
\text { crafting } \rightarrow \text { Happi- } \\
\text { ness at work }\end{array}$ & .362 & .081 & 4.479 & $* * *$ \\
\hline $\begin{array}{l}\text { Relationships' } \\
\text { crafting } \rightarrow \text { Tasks' } \\
\text { crafting }\end{array}$ & .381 & .050 & 7.563 & $* * *$ \\
\hline
\end{tabular}

Table 10 indicates a statistical significant effect for leadership empowerment on relationships' crafting as the effect is high with estimated value of (0.479) and a standard error of (0.040) and a regression critical value of (12.039) and this is a significant value as significance value is $(0.000)$. In addition, there is a statistical significant effect for leadership empowerment on tasks' crafting with estimated value of (0.091) and a standard error of (0.043) and a regression critical value of (2.089) and this is a significant value as significance value is (0.037). Results in table (10) also indicate a statistical significant effect relationships' crafting on happiness at work as the effect is high with estimated value of $(0.362)$ and a standard error of (0.081) and a regression critical value of (4.479) and this is a significant value as significance value is (0.000). Results indicate a statistical significant effect for relationships' crafting on tasks' crafting with estimated value of $(0.381)$ and a standard error of (0.050) and a regression critical value of (7.563) and this is a significant value as significance value is $(0.000)$.

\subsection{Results and recommendations}

There is a significant effect for leadership empowerment on relationships' crafting and this effect is attributed to that leadership empowerment. This enables employees to participate in the administrative process and holding responsibilities as this plays a crucial role in stimulating individuals' behavior toward excellence in job behavior which is positively reflected on achieving happiness among workers reaching to relationships' crafting among them to achieve organizational goals. In addition, this provides with group work as a focus of leadership empowerment to enable employees to cooperate and work with one team spirit until the team mange itself without instruction or supervision.

There is a significant effect for leadership empowerment on tasks' crafting as leadership empowerment is focused on sequence of employees' empowerment beginning with determining their tasks and responsibilities within particular limits and giving them the opportunity to select their roles until fully empowering them and depending on them in decision making which stimulates self-development and self-reliance in problem solving and tasks' achievement as well as regulating priorities, this also achieves many benefits for the organization in general and also for individuals and employees and contributes in achieving an appropriate work environment in addition to employees' feelings of happiness as they achieve their tasks as planned which are in turn facilitated by leadership empowerment.

Results also indicated a statistical significant effect for relationships' crafting on happiness at work as job crafting as a modern administrative approach works on empowering employees and stimulating authorities amendment which leads to improving work outcomes and reinforcing relationships among employees as well as spreading happiness among them. A stimulating method increases motivation toward work and achieving happiness among employees beginning from achievement until belonging and loyalty to the organization.

There was a statistically significant effect for relationship crafting on tasks' crafting and this is interpreted in that making happiness available among employees within work environment through applying leadership empowerment. Enrolling employees in responsibilities and decision making process help in achieving many positive outcomes for the organization such as achieving tasks efficiently and reducing the time necessary to achieve these tasks in addition to achieve working with the one team spirit and constructing an appropriate and efficient communication 
environment within the organization. Furthermore, this goes in line with the result of Russell (2003) which indicated that happiness at work is directly correlated to two important factors. The first is satisfaction regarding treatment within work environment, and the second is dissatisfaction among employees. This result agrees with that of Tims et al. (2013) which indicated an effect for tasks; crafting on individuals and groups' performance.

The importance of leadership empowerment is represented by tasks' and relationships' crafting. As indicated by Wang (2017), the leadership style is significant in stimulating employees to craft tasks and increasing their ability to continuously adjust. It also indicated that tasks' crafting is correlated to higher administration and its efficiency in mandating authorities and including employees in decision making processes.

In light of the results of this study, the following recommendations are suggested:

Offering appropriate work environment beginning with employees' enrolment in decision-making and responsibilities through leadership empowerment and continuously working on developing them until to the organizational belonging and loyalty among them until achieving happiness within the work environment.

The necessity to work with one team spirit and applying the empowerment principle in empowerment within institutions and organizations' administrations in general.

Reinforcing the culture of empowerment with its technical and administrative aspects and mandating more authorities to employees as well as facilitating leaders' administration through constructing the culture of participation among employees and leaders.

\section{References}

A'ffanah, H. (2013). Administrative empowerment and its relationship with work in international NGOs Operating in Gaza (Unpublished PhD Thesis). Ala'zhar University, Gaza.

Ahrarn, A. (2005). Mediahrar: the importance of quality leader/ client interaction and the impact on brand representation. Strategic Communication Capstone Projects.

Altamimi, E. (2004). Creative behavior and its impact on competetive advantage: field study on Jordanian food industrial companies. Albasa'er Journal, 8(2), 159-196.

Ayasrah, M. (2008). Leadership, control and administrative communication. Amman, Jordan. Dar Alhamid for Publication.

Bavik, A., Bavik, Y. L., \& Tang, P. M. (2017). Servant leadership, employee job crafting, and citizenship behaviors: a cross-level investigation. Cornell Hospitality Quarterly, 58(4), 364-373. https://doi.org/10.1177/1938965517719282

Bell, M., \& Njoli, B. (2010). Job crafting: towards a new model of individual job redesign. SA Journal of Industrial Psychology, 36(2), 1-9. https://doi.org/10.4102/sajip.v36i2.841

Berg, J. (2013). Job crafting and meaningful work. Purpose and Meaning in the Workplace, 81, 104. https://doi.org/10.1037/14183-005

Çiğdem, K., \& Belgin, C. (2014). An empirical study on the role of career development programs in organizations and organizational commitment on job satisfaction of employees. Business Administration Department, Istanbul Arel University,
İstanbul, Turkey. American Journal of Business and Management, 3(3), 178-191.

https://doi.org/10.11634/216796061403551

Cohen, A. (2007). Commitment before and after: An evaluation and reconceptualization of organizational commitment. $\mathrm{Hu}$ man Resource Management Review, 17, 336-354. https://doi.org/10.1016/j.hrmr.2007.05.001

Dolan, P., Peasgood, T., \& White, M. (2008). Do we really know what makes us happy? A review of the economic literature on the factors associated with subjective well-being. Journal of Economic Psychology, 29(1), 94-122.

https://doi.org/10.1016/j.joep.2007.09.001

Dutton, V., \& Edmunds, L. (2007). A model of workplace happiness. Selection and Development Review, 23(3), 9.

Esteves, T., \& Lopes, M. (2016). Leading to crafting: The relation between leadership perception and nurses' job crafting. Western Journal of Nursing Research, 39(6), 763-783. https://doi.org/10.1177/0193945916659507

Ghadi, M. (2017). The impact of workplace spirituality on voluntary turnover intentions through loneliness in work. Journal of Economic and Administrative Sciences, 33(1), 81-110. https://doi.org/10.1108/JEAS-03-2016-0005

Golparvar, M., \& Rezaie, A. (2014). Explaining feeling of energy and happiness in the workplace based on components of job crafting. Management and Administrative Sciences Review, 3(1), 41-52.

Grant, A. M., \& Parker, S. K. (2009). Redesigning work design theories: the rise of relational and proactive perspectives. The Academy of Management Annals, 3(1), 317-375. https://doi.org/10.5465/19416520903047327

Jallab, E., \& Alhussieny, K. (2013). Integration and empowerment management. Amman, Jordan. Dar Safa' for Publication.

Kim, M., \& Beehr, T. A. (2018). Can empowering leaders affect subordinates' well-being and careers because they encourage subordinates' job crafting behaviors? Journal of Leadership \& Organizational Studies, 25(2), 184-196.

https://doi.org/10.1177/1548051817727702

Loqasi, W., \& Loqasi, H. (2015). Empowerment leadership and its impact on employee performance (Unpublished master thesis). Djilali Bounaama khemis miliana, University, Algeria.

Lyubomirsky, S. (2005). The benefits of frequent positive affect: Does happiness lead to success? Psychological Bulletin, 131, 803-855. https://doi.org/10.1037/0033-2909.131.6.803

Okurame, D. (2014). Individual factors influencing career growth prospects in contexts of radical organizational changes. International Business Research, 7(10), 74-87. http://www.ccsenet. org/journal/index.php/ibr/article/view/40634

Olsson, L. (2013). Happiness and satisfaction with work commute. Social Indicators Research, 111(1), 255-263.

https://doi.org/10.1007/s11205-012-0003-2

Pearce, C, \& Sims, H. (2002). Vertical versus shared leadership as predictors of the effectiveness of change management teams: An examination of aversive, directive, transactional, transformational, and empowering leader behaviors. Group dynamics: Theory, Research, and Practice, 6(2), 172. https://doi.org/10.1037/1089-2699.6.2.172

Richard, G. V. (2005). International best practices in career development: Review of the literature. International Journal for Educational and Vocational Guidance, 5(2), 189-201. https://doi.org/10.1007/s10775-005-8799-9

Russell, J. A. (2003). Core affect and the psychological construction of emotion. Psychological Review, 110, 145-172.

https://doi.org/10.1037/0033-295X.110.1.145 
Wang, H. (2017). Transformational leadership, adaptability, and job crafting: The moderating role of organizational identification. Journal of Vocational Behavior, 100, 185-195.

https://doi.org/10.1016/j.jvb.2017.03.009

Wrzesniewski, A., \& Dutton, J. E. (2001). Crafting a job: Revisioning employees as active crafters of their work. Academy of Management Review, 26(2), 179-201.

https://doi.org/10.5465/amr.2001.4378011

Tims, M., Bakker, A. B., \& Derks, D. (2013). The impact of job crafting on job demands, job resources, and well-being. Journal of Occupational Health Psychology, 18, 230-240.

https://doi.org/10.1037/a0032141 